\title{
Comunicação
}

[Communication]

\section{Detecção de ácidos nucléicos de Brucella spp., Leptospira spp., herpesvirus bovino e vírus da diarréia viral bovina, em fetos bovinos abortados e em animais mortos no perinatal}

\author{
[Detection of Brucella spp., Leptospira spp., bovine herpesvirus and bovine viral diarrhea virus \\ nucleic acids in aborted fetuses and bovines dead perinatal]

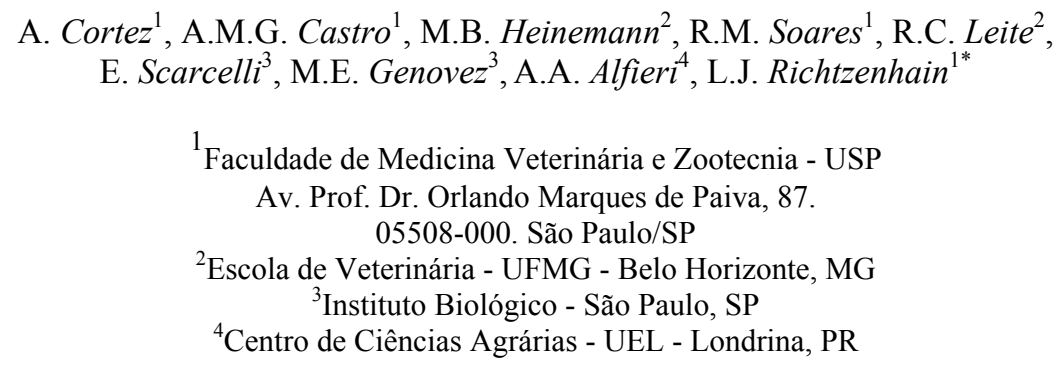

No Brasil, levantamentos sorológicos indicam que infecções pelo vírus da diarréia viral bovina (VDVB), pelo herpesvírus bovino (HVB), pela Brucella spp e Leptospira spp. estão disseminadas (Vasconcellos et al., 1997; Richtzenhain et al., 1999a, 1999b; Paulin e Ferreira Neto, 2003). Todavia, são poucos os trabalhos que mostram a participação desses agentes em alterações reprodutivas mediante diagnóstico direto (Genovez et al., 1993; Pituco et al., 1999; Langoni et al., 1999; Cortez et al., 2001; Scarceli et al., 2004; Takiuchi et al., 2005).

O objetivo deste trabalho, apesar das limitações decorrentes da amostragem de conveniência empregada, constituída por amostras enviadas ao laboratório após o abortamento bovino ou após mortalidade perinatal, foi verificar pela reação em cadeia de polimerase (PCR) a presença de ácidos nucléicos de VDVB, HVB, Brucella spp. e Leptospira spp.

Foram examinados 114 fetos bovinos abortados e 10 bezerros com mortalidade perinatal,

Recebido em 3 de fevereiro de 2006

Aceito em 21 de agosto de 2006

* Autor para correspondência (corresponding author)

E-mail: leonardo@usp.br

Apoio: FAPESP (01/10155-4) provenientes de diferentes estados brasileiros (AL, GO, MG, MS, MT, RS, SP) durante o período de 1997 a 2004, excetuando-se o ano de 2000.

A detecção de DNA de Brucella spp. e Leptospira spp. foi realizada conforme descrito por Richtzenhain et al. (2002). Na detecção do HVB, foram utilizados macerados de pulmões e cérebro para extração de DNA (Chomkzynski et al. 1993). Os primers e as condições de amplificação foram descritos por Ros e Belák (1999).

Para o diagnóstico do VDVB, foi empregada uma heminested PCR (hPCR) direcionada à região 5' não tradutora do vírus. Os primers externos (P1 e P2) foram descritos por Ridpath e Bolin (1998). Para a hPCR, foi desenhado o primer PN2 (5' RCA CCC TWW CAG GCT GT $\left.3^{\prime}\right)$ que trabalha conjuntamente com P1. 
A extração do RNA viral, a partir do homogeneizado de órgãos (fígado, baço, rins e/ou pulmões e/ou cérebro), foi realizada com Trizol $^{1}$, e a síntese do cDNA foi feita utilizando a enzima transcriptase reversa do vírus da leucemia murina - MMLV-RT ${ }^{1}$ e primers randômicos ${ }^{1}$, conforme instruções do fabricante.

A PCR foi realizada com 2,5 $\mu 1$ de cDNA, 200 $\mu \mathrm{M}$ de cada dNTP's, 1x tampão da PCR, 25pmoles dos primers $\mathrm{P} 1$ e $\mathrm{P} 2,1,5 \mathrm{mM}$ de $\mathrm{MgCl}_{2}$ e 2,5U da enzima Taq DNA polimerase platinum $^{1}$ e água ultrapura qsp $50 \mu 1$. As condições de amplificação foram: desnaturação inicial de $94^{\circ} \mathrm{C}$ por $2 \mathrm{~min}$ e 35 ciclos de $94^{\circ} \mathrm{C}$ por $30 \mathrm{~s}, 50^{\circ} \mathrm{C}$ por $30 \mathrm{~s}, 72^{\circ} \mathrm{C}$ por $30 \mathrm{~s}$ e uma extensão final de $72^{\circ} \mathrm{C}$ por $5 \mathrm{~min}$.

A hPCR foi executada num volume final de $50 \mu \mathrm{l}$ com as mesmas concentrações dos reagentes acima mencionados, exceto as dos primers $\mathrm{P} 1 \mathrm{e}$ PN2 (20pmoles). Foram adicionados, ainda, 10\% de glicerol e utilizados $2 \mu \mathrm{l}$ do produto da PCR, nas mesmas condições de amplificação da PCR. Os produtos de amplificação foram analisados de acordo com Sambrook et al. (1989).

Das 124 amostras analisadas, 13,7\% (17/124) foram positivas para Brucella spp., 3,2\% (4/124) para Leptospira spp., 2,4\% (3/124) para HVB e para VDVB e $0,81 \%(1 / 124)$ para a associação de VDVB e HVB. Em 77,4\% (96/124) das amostras, não foi possível detectar nenhum dos agentes estudados.

A predominância de Brucella spp. encontrada nos fetos bovinos e nos animais mortos no período perinatal é confirmada por Genovez et al. (1993), que utilizaram o diagnóstico bacteriológico e por Scarcelli et al. (2004), que empregaram cultura microbiológica e uma multiplex PCR (mPCR).

A baixa detecção de Leptospira spp. difere dos dados de Genovez et al. (1993). Nestes, o número de material positivo ao isolamento e à reação de imunofluorescência indireta $(16 / 257)$ foi o mesmo que o de Brucella abortus. Freqüências maiores foram relatadas por Langoni et al. (1999), que isolaram Leptospira spp. em 12,5\% (15/120) das amostras analisadas. Scarcelli et al. (2004), ao aplicarem o cultivo

\footnotetext{
${ }^{1}$ Invitrogen ${ }^{\circledR}$ CARLSBAD - EUA.
}

bacteriológico e uma mPCR, não encontraram Leptospira spp. em 67 amostras oriundas de abortamentos bovino.

O pequeno número de animais positivos para Leptospira spp. pode ser atribuído ao aumento da utilização da vacinação em nosso meio (Scarcelli et al., 2004) ou ao fato de a infecção estar ocorrendo nas primeiras fases gestacionais, o que ocasionaria perdas embrionárias e retorno do cio (Ellis, 1994). Cabe ressaltar que dos 67 animais dos quais foi possível dispor de informações quanto à idade ou estimá-la, apenas seis eram do terço inicial de gestação.

O resultado de 2,4\% (3/124) de HVB foi menor que o de 9,3\% (15/161) encontrado por Pituco et al. (1999), que utilizaram a imunofluorescência direta. Por meio das técnicas de isolamento viral e semi-nested PCR, Takiuchi et al. (2005) obtiveram porcentagens de detecção do HVB maiores, 25,4\% (14/55).

Os resultados encontrados na investigação do $\operatorname{VDVB}(2,42 \%$ - 3/124) diferem dos 4,8\% (4/83) observados por Pituco et al. (1999), pela reação de imunofluorescência direta e dos 3,2\% (47/1462) encontrados em fetos abortados, natimortos e membranas fetais por isolamento e PCR (Flores et al. 2005).

Embora Murray (1990) descreva associações do VDVB com outros patógenos, apenas um feto apresentou infecção mista entre VDVB e HVB.

Considerando que, à semelhança do presente trabalho, a maioria dos estudos congêneres realizados no país baseou-se em amostragens de conveniência, constituídas por amostras aleatoriamente enviadas ao laboratório, após ocorrência de problema reprodutivo, a comparação dos resultados de freqüência de detecção dos diferentes agentes pesquisados carece de consistência estatística.

A eficiência do diagnóstico laboratorial das doenças reprodutivas depende da sensibilidade e especificidade dos métodos empregados (métodos diretos, indiretos e histopatológicos), da facilidade e da disponibilidade do diagnóstico oferecido, da pressão exercida pelos órgãos competentes em realizar o diagnóstico, da atitude profissional do clínico e da equipe laboratorial em resolver o problema (Murray, 1990). 
Assim, um maior esforço precisa ser realizado para que se possam identificar as causas mais freqüentes de abortamentos, infecciosos ou não, em cada região do país, a fim de que medidas de controle possam ser implementadas.

Palavras-chave: bovino, aborto, feto, PCR, RT-PCR

\begin{abstract}
Samples of 114 bovine fetuses and 10 calves, which dead in perinatal period, were examined for detection of DNA. The most common detected agent was Brucella spp. in 17 samples (13.7\%) followed by Leptospira spp. in 4 cases (3.2\%), bovine herpesvirus (BHV) and bovine viral diarrhea (BVDV) in 3 animals (2.4\%) each, and 1 for the association of BVDV and BHV. In $77.4 \%(96 / 124)$ of the samples it was not possible to detect any agent.
\end{abstract}

Keywords: bovine, abortion, fetuses, PCR, RT-PCR

\section{AGRADECIMENTOS}

Ao Prof. Sílvio Arruda Vasconcellos, por ceder as amostras-padrão de Leptospira spp. Ao médico veterinário Henrique Leomil, pelo auxílio nas necropsias.

\section{REFERÊNCIAS BIBLIOGRÁFICAS}

CHOMCZYNSKI, P. A reagente for the single step simultaneous isolation of RNA, DNA and proteins froms cells and tissue samples. Biotechiniques, v.15, p.532-537, 1993

CORTEZ, A.; SCARCELLI, E.; SOARES, R.M. et al. Detection of Brucella DNA from aborted bovine fetuses by polymerase chain reaction. Aust. Vet. J., v.79, p.500-501, 2001

ELLIS, W.A. Leptospirosis as a cause of reproductive failure Vet. Clin. N. Am.: Food Anim. Pract., v.10, p.463-478, 1994.

FLORES, E.F.; WEIBLEN, R.; VOGEL, F.S.F. et al. A infecção pelo vírus da diarréia viral bovina (BVDV) no Brasil-histórico, situação atual e perspectiva. Pesq. Vet. Bras., v.25 p.125-134, 2005.

GENOVEZ, M.E.; SCARCELLI, E.; ROJAS, S. et al. Isolamento bacteriano de fetos abortados bovinos examinados no Instituto Biológico de São Paulo, no período de 1985 a 1992. Braz. J. Vet. Res. Anim. Sci., v.30, p.107112, 1993.

LANGONI, H.; SOUZA, L.C.; SILVA, A.V. et al. Incidence of leptospiral abortion in Brazilian dairy cattle. Prev. Vet. Med., v.40, p.271-275, 1999.

MURRAY, R.D. A field investigation of causes of abortion in dairy cattle. Vet. Rec., v.127, p.543-547, 1990

PAULIN, L.M.; FERREIRA NETO, J.S. $O$ combate à brucelose bovina: situação brasileira. Funep, 2003. 154p.

PITUCO, E.M.; STEFANO, E.; OKUDA, L.H. et al. Detecção do herpesvírus bovino tipo 1 (HVB-1) e do vírus da diarréia viral bovina pela imunofluorescência direta (IFD) em fetos bovinos abortados. Arq. Inst. Biol. São Paulo, v.66, supl., p.44, 1999. (Resumo).

RICHTZENHAIN, L.J.; BARBARINI, O.; UMEHARA, O. et al. Diarréia viral bovina: levantamento sorológico nos estados de Minas Gerais, Mato Grosso do Sul, São Paulo, Rio de Janeiro, Paraná e Rio Grande do Sul. Arq. Inst. Biol., São Paulo, v.66, p.107-111, 1999a.

RICHTZENHAIN, L.J.; BARBARINI, O.; UMEHARA, O. et al. Rinotraqueíte infecciosa bovina: levantamento sorológico nos estados de Minas Gerais, Mato Grosso do Sul, São Paulo, Rio de Janeiro, Paraná e Rio Grande do Sul. Arq. Inst. Biol., São Paulo, v.66, p.83-88, 1999b.

RICHTZENHAIN, L.J.; CORTEZ, A.; HEINEMANN, M.B. et al. A multiplex PCR for the detection of Brucella spp. and Leptospira spp. DNA from aborted bovine fetuses. Vet. Microbiol., v.87, p.139 - 147, 2002.

RIDPATH, J.F.; BOLIN, S.R. Differentiation of types 1a, $1 \mathrm{~b}$ and 2 bovine viral diarrhea virus (BVDV) by PCR. Mol. Cell. Probes., v.12, p.101-106, 1998.

ROS, C.; BELÁK, S. Studies of the genetic relationship between bovine, caprine, corvine, and reangiferine alphaherpesvirus and improved molecular methods for virus detection and identification. J. Clin. Microbiol., v.37, p.1247$1253,1999$.

SAMBROOK, J.; FRITSCH, E.F.; MANIATIS, T. Molecular cloning: a laboratory manual. 2.ed. Cold Spring: Harbor Laboratory, 1989

SCARCELLI, E.; PIATTI, R.M.; CARDOSO, M.V. Detecção de agentes bacterianos pelas técnicas de isolamento e identificação e PCR- multiplex em fetos bovinos abortados. Rev. Bras. Reprod. Anim., v.28, p.23-27, 2004.

TAKIUCHI, E.; MÉDICI, K.C.; ALFIERI, A.F. et al. Bovine herpesvirus type 1 abortions detected by a semi-nested PCR in Brazilian cattle herds. Res. Vet. Sci., v.79, p.85-88, 2005

VASCONCELLOS, S.A.; BARBARINI JÚNIOR, O.; UMEHARA, O. Leptospirose bovina. Níveis de ocorrência e sorotipos predominantes em rebanhos dos estados de Minas Gerais, São Paulo, Rio de Janeiro, Paraná, Rio Grande do Sul e Mato Grosso do Sul. Período de janeiro a abril de 1996. Arq. Inst. Biol., v.64, p.7-15, 1997. 